\title{
Rotavirus Genotypes in Costa Rica, Nicaragua, Honduras and the Dominican Republic
}

\author{
Lurys Bourdett-Stanziola ${ }^{a-c}$ Eduardo Ortega-Barria ${ }^{a}$ Felix Espinoza $^{c}$ \\ Filemon Bucardo $^{c}$ Carlos Jimenez $^{\mathrm{b}}$ Annabelle Ferrera ${ }^{\mathrm{d}}$

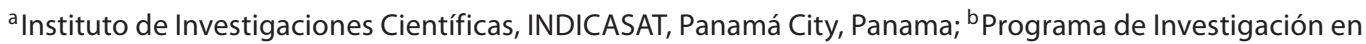 \\ Enfermedades Tropicales (PIET), Heredia, Costa Rica; ' ${ }^{\circ}$ epartamento de Microbiología, Universidad de León, \\ León, Nicaragua; ${ }^{d}$ Departamento de Microbiología, Universidad Nacional Autónoma de Tegucigalpa, \\ Tegucigalpa, Honduras
}

\section{Key Words}

Rotavirus · Genotype $\cdot$ Diarrhea $\cdot$ VP7 $\cdot$ VP4

\begin{abstract}
In this study, 574 stool samples from children with gastroenteritis were obtained from different hospitals in Costa Rica, Honduras, Nicaragua and the Dominican Republic during 2005-2006. Diarrhea stool samples were analyzed for rotavirus by ELISA and typed by the RT-PCR-based method. Unusual strains were detected: G1P6, G2P8, G3P6, G9P4 and mixed infections. Recent studies have indicated that unusual human rotavirus strains are emerging as global strains, which has important implications for effective vaccine development. In this context, the next generation of rotavirus vaccines will need to provide adequate protection against diseases caused not only by mixed infections, but also by unusual G/P combinations.

Copyright $\odot 2010$ S. Karger AG, Base
\end{abstract}

Gastrointestinal illnesses due to rotavirus infections among young children contribute greatly to morbidity and mortality rates in many Latin American countries and other parts of the world. According to previous re- search, the rotavirus is considered responsible, on a global scale, for nearly 611,000 deaths per year in children [1].

The experience and data of previous studies carried out in Central America have demonstrated that gastrointestinal infections are one of the most prominent health problems that contribute to high morbidity and mortality [2-4].

Rotaviruses belong to the Reoviridae family and possess a trilaminar capsid enclosing 11 segments of doublestranded RNA. Rotaviruses are classified into G- and Ptypes according to the antigenic or genetic diversity of the capsid proteins VP7 (G-types) and VP4 (P-types) [5]. Up to now, at least $19 \mathrm{G}$-genotypes and $27 \mathrm{P}$-genotypes have been described [6]. Theoretically, many G/P combinations are possible within the binary system utilized to classify rotavirus genotypes; however, the G1P[8], G2P [4], G3P[8], G4P[8] and G9P[8] combinations are the most commonly identified genotypes worldwide [7]. The proteins VP7 and VP4 are important for vaccine development, as they are the major antigenic targets for virus neutralization [8]. Due to the prominent use of the rotavirus vaccine Rotarix ${ }^{\circledR}$ in South America, Central America and the Caribbean, research efforts in this field are urgent in order to understand the epidemiology, standard diagnostics and characterization of viral strains [9].

\section{KARGER}

Fax +4161306 1234 E-Mail karger@karger.ch www.karger.com
(C) 2010 S. Karger AG, Basel

$0300-5526 / 10 / 0536-0390 \$ 26.00 / 0$

Accessible online at:

www.karger.com/int
Lurys Bourdett-Stanziola

Instituto de Investigaciones Científicas, INDICASAT

Panamá City (Panama)

Tel. +507517 0700, Fax +507 507 0020, E-Mail lurysb@yahoo.com 
Taking into account that rotavirus disease is a global problem and that its epidemiology is relevant to public health, efforts are underway to consolidate a regional network in Central America for the detection and characterization of the most prevalent rotavirus strains circling the region. This effort is headed by the Network for Research and Training of Tropical Diseases in Central America ('NeTropica Net').

We report in this study the circulation of the G- and P-genotypes of rotavirus strains in some Central American countries and the Dominican Republic during 20052006.

In this study, 574 stool samples from children with gastroenteritis were obtained from different hospitals. Of the 574 samples, a total of 166 samples tested positive by ELISA for the rotavirus and were submitted for G- and P-genotype characterization.

The rotavirus samples from the Dominican Republic were collected in Santo Domingo between February and June 2005. Samples were stored on ice and taken to the virology laboratory at the Instituto de Investigaciones Científicas (INDICASAT) in Panama where they were diluted $1: 4$ in $\mathrm{PBS}$ and stored at $-70^{\circ} \mathrm{C}$ for further analysis. From 100 ELISA-positive stool samples, sufficient material was only available in 37 cases; a selection of 7-8 per month were further subjected to reverse transcription (RT)-PCR to determine their VP7 and VP4 genotypes.

The rotavirus samples from Costa Rica were collected from children with gastroenteritis who were admitted to the National Children's Hospital in San Jose between August and October 2005. A total of 129 samples were analyzed by ELISA, of which 39 were positive. From May to June 2006, an additional 25 rotavirus-positive samples (as determined by ELISA) were obtained. All ELISA-positive samples were analyzed by RT-PCR to determine the Gand P-genotypes in the virology laboratory of the School of Veterinary Medicine, National University, National University of Heredia, Costa Rica.

In Nicaragua, 20 rotavirus-positive samples were obtained from May to June 2006 from hospitalized children at the Hospital School of León. G- and P-genotyping were analyzed by RT-PCR for all samples at the Department of Microbiology, University of León, Nicaragua.

In Honduras, a subset of 45 out of 300 rotavirus-positive samples were collected from May to June 2006 at the pediatric service and the pediatric infectology ward at the Hospital Regional Santa Teresa in Comayagua, the Hospital San Francisco in Juticalpa and a private clinic in Tegucigalpa. Twenty-two samples from May and 23 from June were tested for rotavirus by genotyping for the VP7
(G-type) and VP4 (P-type) genes by RT and multiplex PCR at the Department of Microbiology, National University, Tegucigalpa, Honduras.

In Nicaragua and Honduras, the primary detection method for fecal rotavirus was performed by a rotavirus immunochromatographic assay test (Rota-Strip; BioConcept, Brussels, Belgium). In Costa Rica and the Dominican Republic, screening was performed by Rota IDEA (DakoCytomation Ltd., UK) to detect the VP6 antigen according to the manufacturer's instructions.

To determine the G- and P-genotypes, the specimens were analyzed by nested multiplex RT-PCR assays to determine the most common G-genotypes (G1-G4, G5 and G8) and P-genotypes (P[4], P[6], P[8] and P[9], P[10]). Primers and procedures were performed as previously described [10]. This method is a modification of the original methods described by Gouvea et al. [11] for G-typing and Gentsch et al. [12] for P-typing. This methodology has been adopted by the Central American laboratories participating in the network [10].

In agreement with previous studies performed in the region [2-4], this study shows the presence of the most predominant rotavirus types that have been encountered globally. However, uncommon genotype combinations and rare genotypes were present as well. The detected uncommon rotavirus genotype combinations G1P[6], G2P[8] and G3P[6] have been reported before in 20022003 [4]. Additionally, uncommon G9P[4] rotaviruses were detected. The G1P[8] type was the most frequent rotavirus type in the Dominican Republic and Costa Rica during 2005, which agrees with the first reported outbreak in the Dominican Republic during 2003 [4].

In the Dominican Republic, the most prevalent strain (in 2005) was G1P[8] (29\%), followed by G2P[4] (22\%), G3P[8] (13\%), G1P[6] (10\%) and G3P[6] (5\%). In addition, 2 mixed infections, 1 sample with G1+G3 and 1 sample with $\mathrm{G} 1+\mathrm{G} 2$ were detected. In both, the associated Pgenotype(s) could not be determined (table 1).

In Costa Rica, the most prevalent strain during 2005 was G1P[8] (69\%), G2P[8] (3\%) and G1P[6] (10\%). In 2006, G9P [8] was the most prevalent strain (60\%), followed by G9P[4] (24\%). In Nicaragua, the genotype G4P[8] (60\%) was the most prevalent type, followed by G9P [8] (35\%). In Honduras, infection by G2P[4] (42\%) appeared to be the most frequent cause of the rotavirus outbreak, occurring primarily in children under 1 year of age. Other genotypes encountered were G4P[8] (16\%) and G9P[8] (13\%; table 1).

In Nicaragua and Honduras, the genotype G4P[8] was detected in 60 and 16\%, respectively, of stool sam- 
Table 1. Distribution of G- and P-types of rotavirus strains isolated during gastroenteritis in Costa Rica, Nicaragua, Honduras and the Dominican Republic, 2005-2006

\begin{tabular}{|c|c|c|c|c|c|}
\hline \multirow{2}{*}{$\begin{array}{l}\text { Genotypes } \\
\text { G and P }\end{array}$} & \multicolumn{2}{|l|}{2005} & \multicolumn{3}{|l|}{2006} \\
\hline & $\begin{array}{l}\text { Costa } \\
\text { Rica }\end{array}$ & $\begin{array}{l}\text { Dominican } \\
\text { Republic }\end{array}$ & $\begin{array}{l}\text { Costa } \\
\text { Rica }\end{array}$ & Nicaragua & Honduras \\
\hline G1P[6] & $4(10)$ & $4(11)$ & & & \\
\hline G1P[8] & $27(69)$ & $11(30)$ & & & \\
\hline G2P[4] & & $8(22)$ & & & $19(42)$ \\
\hline G2P [8] & $1(3)$ & & & & \\
\hline G3P[6] & & $2(5)$ & & & \\
\hline G3P[8] & & $5(13)$ & & & \\
\hline G4P [8] & & & & $12(60)$ & $7(16)$ \\
\hline G9P[4] & & & $6(24)$ & & \\
\hline G9P [8] & & & $15(60)$ & $7(35)$ & $6(13)$ \\
\hline $\mathrm{G} ? \mathrm{P}[8]$ & & & $1(4)$ & & \\
\hline $\mathrm{G} 1+\mathrm{G} 2 \mathrm{P}[?]$ & & $1(3)$ & & & \\
\hline G1+G3P[?] & & $1(3)$ & & & \\
\hline Untyped G & $7(18)$ & $5(14)$ & $3(12)$ & $1(5)$ & $13(28)$ \\
\hline Untyped P & 7 & 7 & 3 & 1 & 14 \\
\hline Total & 39 & 37 & 25 & 20 & 45 \\
\hline
\end{tabular}

Figures in parentheses are percentages.

ples from children with gastroenteritis. This genotype was detected in Costa Rica in the study from 2002 to 2003 [4]. The G4P[8] was responsible for the outbreak of gastroenteritis at the beginning of 2005 in Nicaragua. It was most commonly identified in those regions where fatal cases in children occurred [2]. In addition, this strain has been reported in other countries of the world [13]. Furthermore, in one study, the G4P[8] genotype was considered to be the re-emergent strain in Ireland [14].

In Honduras, at least three genotypes were observed to be simultaneously circulating during the research period; however, it appears that the genotype G2P[4] (42\%) contributed to the majority of cases in Honduras and was also detected in the Dominican Republic in 2005. This genotype is considered, along with G1P[8], to be the most frequent combination in humans [7]. The remarkable reemergence of G2P[4] during the last few years seems to reflect a continental phenomenon [7].

During 2006 in Costa Rica, the combinations G9P[8] and G9P[4] were detected; however, in Nicaragua and Honduras, only the G9P [8] combination was found.
Worldwide, the G9 genotype has recently been considered as emergent [15] and has been found in different Ptype combinations in Brazil [16]. Even though the quantity of the analyzed samples is small, it is important to note that G9 genotypes reappeared in Costa Rica in 2006 where it had already been detected in 2002-2003 [4].

As the Central American countries are considered attractive by Asian and European populations, the high frequency of immigration and travelling constitutes a potential source for the introduction of new genotypes into the local population.

In response to current reports of unusual rotavirus strains in Central American countries that are also being reported around the globe, we believe that vigilance programs in the postvaccination era must be set into action in an attempt to respond to pending queries regarding the potential of reassortments and the emergence of new genotypes. Studies made on the phylogenetics of rotavirus have demonstrated differences in the lineage and sublineage of genotypes, highlighting the great genetic variability of rotavirus [17]. In this context, the immunogenicity and efficacy of rotavirus vaccines may be challenged by the evolution of the rotavirus viral genome.

As mixed infections were detected in the Dominican Republic, a prerequisite for reassortment events, co-surveillance of animal and human rotavirus strains will be vital in order to better understand the relationships between co-circulating viruses, as well as assessing any relevant vaccination programs. Thus, it is imperative to undertake this investigation in Central America, where socioeconomic situations are unsatisfactory and in some countries of the region, such as the Dominican Republic, farm animals and humans coexist in the same house.

For rotavirus characterization, the use of multiplex PCR in the identification of the VP7 and VP4 genes should be handled with caution. A low percentage of samples were untypeable for $G$ and $P$; the possibility of unspecific primer binding has to be taken into consideration, mainly as the accumulation of point mutations and diversification on specific lineages has been reported [18].

We also believe that for VP4 it is possible that genotypes are unusual because we used common primers for the detection of group P.

In light of these considerations, additional experiments are necessary to confirm the results obtained during G- and P-typing. In particular, the confirmation of the high frequency of unusual G/P combinations found by sequence analysis is recommended. 
With the aid of 'NeTropica Net', we are establishing a vigilance program on the rotavirus strains in Central American countries, with the aim of not only keeping a monitoring record on the circulating strains, but also with the intention of unifying the protocols in all investigatory laboratories in Central American countries.

\section{Acknowledgments}

We would like to thank the Network for Research and Training of Tropical Diseases in Central America (NeTropica; grant 2005-7), Fundación para el Avance de la Investigación Clínica y Translacional (FAICYT) in Panama (grant rota-023) and Programa Iberoamericano de Ciencia y Tecnología (CYTED; grant Net-206RT0289) for financially supporting this research.

\section{References}

1 Parashar UD, Gibson CJ, Bresee JS, Glass RI: Rotavirus and severe childhood diarrhea. Emerg Infect Dis 2006;12:304-306.

$\checkmark 2$ Bucardo F, Karlsson B, Nordgren J, Paniagua M, González A, Amador J, Espinoza F, Svensson L: Mutated G4P[8] rotavirus associated with a nationwide outbreak of gastroenteritis in Nicaragua in 2005. J Clin Microbiol 2007; 45:990-997.

-3 Espinoza F, Bucardo F, Paniagua M, Svensson L, Hallander HO, Bondeson K: Shifts of rotavirus $G$ and $P$ types in Nicaragua 20012003. Pediatr Infect Dis J 2006;25:10781080.

4 Bourdett-Stanziola L, Jiménez C, OrtegaBarría E: Diversity of human rotavirus $G$ and $\mathrm{P}$ genotypes in Panama, Costa Rica and the Dominican Republic. Am J Trop Med Hyg 2008;79:921-924.

5 Kapikian A, Hoshino Y, Chanock R: Rotaviruses; in Knipe D, Howley PM, et al (eds): Fields Virology, ed 4. Philadelphia, Lippincott Williams \& Wilkins, 2001, pp 1787 1834.

6 Ciarlet M, Hoffmann C, Lorusso E, Baselga R, Cafiero MA, Bányai K, Matthijnssens J, Parreño V, de Grazia S, Buonavoglia C, Martella V: Genome characterization of novel group A lamb rotavirus isolated in Zaragoza, Spain. Virus Genes 2008;37:250-265.
7 Santos N, Hoshino Y: Global distribution of rotavirus serotypes/genotypes and its implication for the development and implementation of an effective rotavirus vaccine. Rev Med Virol 2005;15:29-56.

8 Estes MK: Rotaviruses and their replication; in Knipe DM, Howley RM, et al (eds): Fields Virology, ed 4. Philadelphia, Lippincott Williams \& Wilkins, 2001, pp 1747-1785.

$\checkmark 9$ Linhares AC, Velázquez FR, Pérez-Schael I, Sáez-Llorens X, Abate H, Espinoza F, López P, Macías-Parra M, Ortega-Barría E, RiveraMedina DM, Rivera L, Pavía-Ruz N, Nuñez E, Damaso S, Ruiz-Palacios GM, De Vos B, O’Ryan M, Gillard P, Bouckenooghe A, Human Rotavirus Vaccine Study Group: Efficacy and safety of an oral live attenuated human rotavirus vaccine against rotavirus gastroenteritis during the first 2 years of life in Latin American infants: a randomised, double-blind, placebo-controlled phase III study. Lancet 2008;5;371:1181-1189.

10 Iturriza-Gómara M, Kang G, Gray J: Rotavirus genotyping: keeping up with an evolving population of human rotaviruses. J Clin Virol 2004;31:259-265.

-11 Gouvea V, Glass P, Woods K, Taniguchi HF, Clark B, Forrester B, Fang ZY: Polymerase chain reaction amplification and typing of rotavirus nucleic acid from stool specimens. J Clin Microbiol 1990;28:276-282.

12 Gentsch JR, Glass R, Woods P, Gouvea V, Gorziglia M, Flores J, Das B, Bhan M: Identification of group A rotavirus gene 4 types by polymerase chain reaction. J Clin Microbiol 1992;30:1365-1373.
13 Arista S, Giammanco GM, De Grazia S, Colomba C, Martella V: Genetic variability among serotype G4 Italian human rotaviruses. J Clin Microbiol 2005;43:1420-1425.

14 Feeney SA, Mitchell SJ, Mitchell F, Wyatt DE, Fairley D, McCaughey C, Coyle PV, O’Neill $\mathrm{HJ}$ : Association of the $\mathrm{G} 4$ rotavirus genotype with gastroenteritis in adults. J Med Virol 2006;78:1119-1123.

15 Castello AA, Arvay ML, Glass RI, Gentsch J: Rotavirus strain surveillance in Latin America: a review of the last nine years. Pediatr Infect Dis J 2004;23:S168-S172.

16 Araújo IT, Ferreira MSR, Fialho AM, Assis RM, Cruz CM, Rocha M, Leite JPG: Rotavirus genotypes $P[4] \mathrm{G} 9, \mathrm{P}[6] \mathrm{G} 9$, and $\mathrm{P}[8] \mathrm{G} 9$ in hospitalized children with acute gastroenteritis in Rio de Janeiro, Brazil. J Clin Microbiol 2001;39:1999-2001.

$\checkmark 17$ Araújo IT, Heinemann MB, Mascarenhas JDAP, Assis RMS, Fialho AM, Leite JPG: Molecular analysis of the NSP4 and VP6 genes of rotavirus strains recovered from hospitalized children in Rio de Janeiro, Brazil. J Med Microbiol 2007;56:854-859.

$>18$ Espinola EE, Parra GI, Russomando G, Arbiza J: Genetic diversity of the VP4 and VP7 genes affects the genotyping of rotaviruses: analysis of Paraguayan strains. Infect Genet Evol 2008;1:94-99. 